\title{
PENGARUH PUPUK PROCAL DAN PUPUK KANDANG KAMBING TERHADAP PERTUMBUHAN DAN PRODUKSI TANAMAN TOMAT (Lycopersicon esculentum MILL.) VARIETAS TIMOTY F1
}

\author{
Djohanis Salianan ${ }^{1}$ \\ ${ }^{1}$ Agroteknologi, Fakultas Pertanian, Universitas 17 Agustus 1945 Samarinda 75124, \\ Indonesia. \\ Jl. Ir. H. Juanda No.80 Samarinda, 75124, Indonesia. \\ E-Mail: djohanissalianan@yahoo.com
}

\begin{abstract}
ABSTRAK
Pengaruh Pupuk Procal dan Pupuk Kandang Kambing terhadap Pertumbuhan dan Produksi Tanaman Tomat (Lycopersicon esculentum Mill.) Varietas Timoty F1. Tujuan penelitian adalah untuk : (1) mengetahui pengaruh pupuk organik Procal dan pupuk kandang kambing serta interaksinya terhadap pertumbuhan dan hasil produksi tanaman tomat Varietas Timoty F1; dan (2) mengetahui dosis pupuk organik Procal dan pupuk kandang kambing yang tepat untuk memperoleh produksi tanaman tomat Varietas Timoty F1 yang maksimal.

Penelitian menggunakan Percobaan Faktorial 4 x 4 dalam Rancangan Acak Lengkap (RAL) yang diulang sebanyak 3 kali. Faktor pertama adalah dosis pupuk Procal (P) yang terdiri atas 4 taraf : tanpa pupuk Procal (p0), 5 g polibag $^{-1}$ (p1). 10 g polibag $^{-1}$ (p2); dan 15 g polibag $^{-1}$ (p3). Faktor kedua adalah dosis pupuk kandang kambing (K) terdiri atas 4 taraf : tanpa pupuk kandang kambing (k0), $300 \mathrm{~g}^{\text {polibag }}{ }^{-1}(\mathrm{k} 1), 600 \mathrm{~g}$ polibag $^{-1}(\mathrm{k} 2)$, dan $900 \mathrm{~g} \mathrm{polibag}^{-1}(\mathrm{k} 3)$.

Hasil penelitian menunjukkan bahwa : (1) pemberian pupuk Procal berpengaruh nyata sampai berpengaruh sangat nyata terhadap tinggi tanaman pada umur 14 dan 40 hari setelah tanam dan pada saat panen, lingkar batang pada umur 14 hari setelah tanam dan pada saat panen, jumlah buah per tanaman, dan berat buah per tanaman. Berat buah paling tinggi dihasilkan pada perlakuan $15 \mathrm{~g}$ polibag $^{-1}$ (p3) yaitu 3,07 $\mathrm{kg} \mathrm{tanaman}^{-1}$, sedangkan yang paling rendah dihasilkan pada perlakuan tanpa pupuk organik Procal (p0) yaitu 2,04 kg tanaman $^{-1}$; (2) pemberian pupuk kandang kambing berpengaruh nyata sampai berpengaruh sangat nyata terhadap tinggi tanaman pada umur 40 hari setelah tanam dan pada saat panen, lingkar batang pada umur 14 hari setelah tanam dan pada saat panen, jumlah buah per tanaman, dan berat buah per tanaman. Berat buah paling tinggi dihasilkan pada perlakuan $900 \mathrm{~g} \mathrm{polibag}^{-1}(\mathrm{k} 3)$ yaitu 2,97 $\mathrm{kg}_{\text {tanaman }}{ }^{-1}$, sedangkan yang paling rendah dihasilkan pada perlakuan tanpa pupuk kandang kambing (k0) yaitu 1,98 $\mathrm{kg} \operatorname{tanaman}^{-1}$; dan (3) interaksi antara pupuk Procal dan pupuk kandang kambing berpengaruh tidak nyata terhadap tinggi tanaman pada umur 14 dan 40 hari setelah tanam dan pada saat panen, lingkar batang pada umur 14 dan 40 hari setelah tanam dan pada saat panen, dan berat buah per tanaman, tetapi berpengaruh sangat nyata terhadap jumlah buah per tanaman.
\end{abstract}

Kata kunci : Pupuk kandang, Pupuk procal, tomat.

\begin{abstract}
Effect of Procal Fertilizer and Goat Organic Fertilizer on the Growth and Yield of Tomato (Lycopersicon esculentum Mill.) Timoty F1 Variety. The research objective were to study the effect of Procal fertilizer and goat organic fertilizer and its interaction on the growth and yield of tomato and also to find the proper dosage of Procal fertilizer and goat organic fertilizer for obtaining the best growth and yield of tomato.

The research used Completely Randomized Design (CRD) in $4 \times 4$ Factorial Experiment and three replications. The first factor was the dosage of Procal fertilizer $(P)$ consisting of 4 levels : no Procal fertilizer application (p0), $5 \mathrm{~g}_{\text {polybag }}^{-1}(\mathrm{pl}), 10 \mathrm{~g}_{\text {polybag }^{-1}}(\mathrm{p} 2) ;$ and $15 \mathrm{~g}_{\text {polybag }}^{-1}$ (p3). The second factor was the dosage of goat organic fertilizer $(K)$ consisting of 4 levels : no goat organic fertilizer application ( $k 0), 300 \mathrm{~g} \mathrm{polybag}^{-1}(\mathrm{kl}), 600 \mathrm{~g} \mathrm{polybag}^{-1}(\mathrm{k} 2)$; and $900 \mathrm{~g} \mathrm{polybag}^{-1}(\mathrm{k} 3)$.

The results of the research showed that: (1) the Procal fertilizer treatment affected significantly until very significantly on the plant lenght at age 14 and 40 days after planting and at harvest time, circle of stem at
\end{abstract}


age 14 days after planting and at harvest time, number of fruit and fruit weight per plant. The highest production was produced at $15 \mathrm{~g}_{\text {polybag }}^{-1}$ (p3) treatment of 3,07 $\mathrm{kg}_{\text {plant }}{ }^{-1}$, while the least one was produced at the no Procal fertilizer treatment (p0) of 2,04 $\mathrm{kg} \mathrm{plant}^{-1}$; (2) the goat organic fertilizer treatment affected significantly until very significantly on the plant lenght at age 40 days after planting and at harvest time, circle of stem at age 14 days after planting and at harvest time, number of fruit and fruit weight per plant. The highest production was produced at $900 \mathrm{~g}$ polybag $^{-1}(\mathrm{k3})$ treatment of $2,97 \mathrm{~kg} \mathrm{plant}^{-1}$, while the least one was produced at the no goat organic fertilizer treatment ( $\mathrm{kO}$ ) of $1,98 \mathrm{~kg} \mathrm{plant}^{-1}$; and (3) the interaction treatment between Procal fertilizer and goat organic fertilizer no affect significantly on the all parameters, but affected significantly on the number of fruit per plant.

Key words : Goat Organic Fertilizer, Procal Fertilizer, Tomato.

\section{PENDAHULUAN}

Indonesia merupakan salah satu negara yang bisa dikatakan kaya akan sumber daya alam (SDA). Kekayaan sumber daya alam itu sendiri beraneka ragam, baik dari sektor perikanan, kehutanan, peternakan maupun sektor pertanian. Salah satu sumber daya alam dari sektor pertanian adalah tanaman hortikultura baik buah-buahan maupun sayur-sayuran. Pada umumnya tanaman komoditas pertanian sangat dibutuhkan masyarakat seperti halnya tanaman hortikultura yaitu buah tomat (Lycopersicon esculentum Mill.).

Buah tomat saat ini merupakan salah satu komoditas hortikultura yang bernilai ekonomi tinggi dan masih memerlukan penanganan serius, terutama dalam hal peningkatan hasilnya dan kualitas buahnya. Rendahnya produksi tomat di Indonesia kemungkinan disebabkan varietas yang ditanam tidak cocok, kultur teknis yang kurang baik atau pemberantasan hama/penyakit yang kurang efisien (Kartapradja dan Djuariah, 1992).

Kemampuan tomat untuk dapat menghasilkan buah sangat tergantung pada interaksi antara pertumbuhan tanaman dan kondisi lingkungannya. Faktor lain yang menyebabkan produksi tomat rendah adalah penggunaan pupuk yang belum optimal serta pola tanam yang belum tepat. Upaya untuk menanggulangi kendala tersebut adalah dengan perbaikan teknik budidaya. Salah satu teknik budidaya tanaman yang diharapkan dapat meningkatkan hasil dan kualitas tomat adalah pemilihan dan aplikasi pupuk yang tepat dalam budidaya tomat tersebut.

Pupuk merupakan salah satu sumber nutrisi penting yang dibutuhkan oleh tanaman dalam pertumbuhan dan perkembangannya. Biasanya pupuk dapat dibedakan menjadi dua yaitu pupuk organik dan pupuk anorganik. Dengan menggunakan pupuk maka dapat meningkatkan produksi dari suatu komoditi pertanian khususnya buah tomat. Namun demikian, pemakaian pupuk anorganik secara terus menerus, berlebihan dan tidak berimbang ternyata menimbulkan dampak negatif terhadap lingkungan. Untuk mencegah dampak negatif tersebut maka alternatif yang diambil yaitu dengan upaya pembudidayaan tanaman menggunakan pupuk organik sebagai bagian dari sistem pertanian organik secara berkesinambungan (Novizan, 2005).

Salah satu jenis pupuk yang dapat diaplikasikan pada tanah yang bereaksi masam seperti Ultisols adalah Procal. Pupuk Procal diproduksi melalui proses rekayasa teknologi tertentu sehingga terjamin memiliki kandungan kapur aktif yang tinggi serta dilengkapi dengan beberapa unsur hara tambahan, dosis penggunaannya lebih hemat (ekonomis dibandingkan penggunaan kapur pertanian, dan lebih cepat berekasi dengan tanah (PT Pertani Persero, 2016). 
Di samping menggunakan pupuk Procal, untuk meningkatkan produksi tanaman dapat pula dilakukan dengan pemberian pupuk organik. Pupuk organik adalah unsur hara yang berasal dari sisa-sisa makhluk hidup yang digunakan untuk memperbaiki sifat fisik tanah, sifat kimia tanah dan sifat biologis tanah. Penggunaan pupuk organik yang berasal dari kotoran hewan (pupuk kandang) dapat bermanfaat bagi pertumbuhan tanaman dan lebih ramah lingkungan (Sutejo, 1987).

Pupuk kandang merupakan sumber unsur hara bagi tanaman yang sangat murah dan mudah diperoleh. Pupuk kandang kambing merupakan pupuk kandang yang mudah terdekomposisi di dalam tanah, disebabkan oleh pupuk kandang kambing merupakan jenis pupuk kandang panas yang relatif banyak mengandung nitrogen dan memiliki kadar air rendah, sehingga mudah didekomposisi oleh organisme dalam tanah (Lingga dan Marsono, 2003).

Tujuan penelitian adalah : (1) untuk mengetahui pengaruh pupuk organik Procal dan pupuk kandang kambing serta interaksinya terhadap pertumbuhan dan hasil produksi tanaman tomat varietas Timoty F1; dan (2) untuk mengetahui dosis pupuk organik Procal dan pupuk kandang kambing yang tepat untuk memperoleh produksi tanaman tomat varietas Timoty F1 yang maksimal.

\section{METODA PENELITIAN}

\subsection{Tempat dan Waktu}

Penelitian ini dilaksanakan di Kecamatan Kaliorang Kabupaten Kutai Timur. Pada bulan Maret-Juni 2015.

\subsection{Bahan dan Alat}

Bahan yang digunakan dalam penelitian yaitu antara lain : bibit unggul Tomat varietas Timoty F1, pupuk Procal, pupuk kandang kambing dan nematisida Furadan 3 G. Alat yang digunakan yaitu : cangkul, parang, garu, ajir, tugal, palu, tali rapia, timbangan analitik, meteran, gembor, papan nama, argo, polibag besar ukuran $20 \mathrm{~cm} \times 30 \mathrm{~cm}$, polibag kecil ukuran $10 \mathrm{~cm} \times 15 \mathrm{~cm}$, gergaji, pisau, alat tulis, kalkulator, kamera, laptop, dan printer.

\subsection{Rancangan Penelitian}

Penelitian ini dilakukan dengan menggunakan Percobaan Faktorial 4 x 4 dalam Rancangan Acak Lengkap (RAL) yang diulang sebanyak 3 kali. Faktor pertama adalah dosis pupuk Procal (P) terdiri atas 4 taraf, yaitu : tanpa pupuk Procal (p1), 5 g polibag $^{-1}$ setara dengan 5 ton $\mathrm{ha}^{-1}$ (p1), $10 \mathrm{~g}$ polibag $^{-1}$ setara dengan 10 ton $\mathrm{ha}^{-1}$ (p2), dan 15 g polibag $^{-1}$ setara dengan 15 ton ha $^{-1}(\mathrm{p} 3)$. Faktor kedua adalah dosis pupuk kandang kambing ( $\mathrm{K}$ ) terdiri atas 4 taraf, yaitu : tanpa pupuk kandang kambing (k0), 300 g polibag $^{-}$ ${ }^{1}(\mathrm{k} 1), 600 \mathrm{~g}_{\text {polibag }}{ }^{-1}(\mathrm{k} 2)$, dan $900 \mathrm{~g}$ polibag $^{-1}(\mathrm{k} 3)$.

\subsection{Pelaksanaan Penelitian}

Kegiatan-kegiatan yang dilaksanakan dalam penelitian diantaranya adalah : (1) persiapan media tanam, (2) persiapan bibit, (3) pemberian perlakuan pupuk kandang kambing, (4) penanaman bibit, (5) pemberian perlakuan pupuk Procal, pemeliharaan tanaman (penyiraman air, penyulaman, penyiangan gulma, pengikatan tanaman pada ajir kayu, pembumbunan tanaman, dan (7) pemanenan.

\subsection{Pengamatan dan Pengumpulan Data}

Data yang diamati dan dikumpulkan dalam penelitian ini terdiri atas : (1) tinggi tanaman $(\mathrm{cm})$ pada saat tanaman berumur 14 dan 40 hari 
setelah tanam dan pada saat panen pertama, (2) lingkar batang $(\mathrm{cm})$ pada saat tanaman berumur 14 dan 40 hari setelah tanam dan pada saat panen pertama, (3) jumlah buah (buah tanaman $^{-1}$ ) dari panen pertama sampai dengan panen terakhir (panen tahap ke 13), dan berat buah ( $\left.\mathrm{kg} \operatorname{tanaman}^{-1}\right)$ diamati dengan menjumlahkan hasil penimbangan semua produksi buah dari panen pertama sampai dengan panen terakhir (panen tahap ke 13).

\subsection{Analisis Data}

Untuk mengetahui pengaruh pupuk Procal dan pupuk kandang kambing serta interaksinya terhadap pertumbuhan dan produksi tanaman tomat varietas Timoty F1 dilakukan dengan menganalisis data hasil pengamatan dengan sidik ragam.

Bila hasil sidik ragam berpengaruh tidak nyata yang menunjukkan $\mathrm{F}$ hitung $\leq \mathrm{F}$ tabel 5\% maka tidak dilakukan uji lanjutan, tetapi bila hasil sidik ragam berpengaruh nyata atau sangat nyata yang menunjukkan $\mathrm{F}$ hitung $>\mathrm{F}$ tabel $5 \%$ atau $1 \%$, maka untuk membandingkan dua rata-rata perlakuan dilakukan dengan uji lanjutan dengan uji Beda Nyata Terkecil (BNT) taraf $5 \%$. Rumus umum Uji BNT yaitu:

$$
\text { BNT } 5 \%=\mathrm{t} \text {-tabel }(\alpha, \mathrm{db}) \times \sqrt{\frac{2 \mathrm{KT} \text { Galat }}{\mathrm{r}}}
$$

3. HASIL PENELITIAN DAN dan pupuk kandang kambing serta PEMBAHASAN interaksinya terhadap pertumbuhan dan hasil tanaman tomat varietas Timoty F1 disajikan pada Tabel 1.

\subsection{Hasil Penelitian}

Hasil penelitian menunjukkan bahwa perlakuan pemberian pupuk Procal

Tabel 1. Rekapitulasi Hasil Penelitian Pengaruh Pupuk Procal dan Pupuk Kandang Kambing serta Interaksinya terhadap Pertumbuhan dan Produksi Tanaman Tomat Varietas Timoty F1

\begin{tabular}{|c|c|c|c|c|c|c|c|c|}
\hline \multirow[t]{2}{*}{ Faktor Perlakuan } & \multicolumn{3}{|c|}{ Tinggi Tanaman $(\mathrm{cm})$} & \multicolumn{3}{|c|}{ Lingkar Batang $(\mathrm{cm})$} & \multirow{2}{*}{$\begin{array}{l}\text { Jumlah } \\
\text { Buah } \\
\text { (buah tan } \\
\text { 1) }\end{array}$} & \multirow{2}{*}{$\begin{array}{l}\text { Berat } \\
\text { Buah } \\
\text { (buah } \\
\tan ^{-1} \text { ) }\end{array}$} \\
\hline & 14 HST & $40 \mathrm{HST}$ & $\begin{array}{c}\text { Saat } \\
\text { Panen }\end{array}$ & 14 HST & $40 \mathrm{HST}$ & $\begin{array}{l}\text { Saat } \\
\text { Panen }\end{array}$ & & \\
\hline Pupuk Procal (P) & $*$ & $* *$ & $* *$ & $*$ & tn & $* *$ & $* *$ & $* *$ \\
\hline $\begin{array}{l}\text { Tanpa pupuk Procal } \\
\text { (p0) }\end{array}$ & $29,84 \mathrm{c}$ & $71,00 \mathrm{~b}$ & $90,25 \mathrm{c}$ & $0,47 \mathrm{~b}$ & 0,52 & $0,73 \mathrm{c}$ & $45,17 \mathrm{c}$ & $2,04 \mathrm{~d}$ \\
\hline $5 \mathrm{~g} \mathrm{polibag}^{-1}(\mathrm{p} 1)$ & 30,92 & $70,76 \mathrm{~b}$ & 90,50 & $0,47 \mathrm{~b}$ & 0,53 & $0,75 \mathrm{a}$ & $56,09 \mathrm{~b}$ & $2,55 \mathrm{c}$ \\
\hline
\end{tabular}




\begin{tabular}{|c|c|c|c|c|c|c|c|c|}
\hline & $\mathrm{ab}$ & & $\mathrm{bc}$ & & & & & \\
\hline $10 \mathrm{~g}_{\text {polibag }^{-1}}(\mathrm{p} 2)$ & $30,50 \mathrm{~b}$ & $73,00 \mathrm{a}$ & $\begin{array}{l}91,25 \\
\mathrm{ab}\end{array}$ & $0,47 \mathrm{~b}$ & 0,54 & $0,74 \mathrm{~b}$ & $56,25 \mathrm{~b}$ & $2,68 \mathrm{~b}$ \\
\hline 15 g polibag $^{-1}(\mathrm{p} 3)$ & $31,34 \mathrm{a}$ & $73,50 \mathrm{a}$ & $92,00 \mathrm{a}$ & $0,48 \mathrm{a}$ & 0,54 & $0,75 \mathrm{a}$ & $65,58 \mathrm{a}$ & $3,07 \mathrm{a}$ \\
\hline $\begin{array}{l}\text { Pupuk Kandang } \\
\text { Kambing (K) }\end{array}$ & tn & $* *$ & $*$ & $*$ & tn & $* *$ & $* *$ & $* *$ \\
\hline $\begin{array}{l}\text { Tanpa pukan } \\
\text { kambing (k0) }\end{array}$ & 30,42 & $70,92 \mathrm{c}$ & $90,25 \mathrm{~b}$ & $0,46 \mathrm{c}$ & 0,52 & $0,73 \mathrm{c}$ & $43,67 \mathrm{~d}$ & $1,98 \mathrm{c}$ \\
\hline $300 \mathrm{~g} \mathrm{polibag}^{-1}(\mathrm{k} 1)$ & 30,17 & $71,42 \mathrm{c}$ & $90,92 \mathrm{~b}$ & $0,47 \mathrm{~b}$ & 0,53 & $0,74 \mathrm{~b}$ & $56,00 \mathrm{c}$ & $2,61 \mathrm{~b}$ \\
\hline 600 g polibag $^{-1}(\mathrm{k} 2)$ & 31,00 & $72,34 \mathrm{~b}$ & $90,83 \mathrm{~b}$ & $0,47 \mathrm{~b}$ & 0,54 & $0,74 \mathrm{~b}$ & $59,75 \mathrm{~b}$ & $2,77 \mathrm{a}$ \\
\hline $900 \mathrm{~g} \mathrm{polibag}^{-1}(\mathrm{k} 3)$ & 31,00 & $73,59 \mathrm{a}$ & $92,00 \mathrm{a}$ & 0,48 a & 0,54 & $0,76 \mathrm{a}$ & $63,67 \mathrm{a}$ & $2,97 \mathrm{a}$ \\
\hline Interaksi (P x K) & tn & tn & tn & tn & tn & tn & $* *$ & tn \\
\hline p0k0 & 29,67 & 69,33 & 89,67 & 0,46 & 0,51 & 0,72 & $38,00 \mathrm{i}$ & 1,65 \\
\hline p0k1 & 30,33 & 69,67 & 89,67 & 0,46 & 0,52 & 0,75 & $41,33 \mathrm{i}$ & 1,79 \\
\hline p0k2 & 30,33 & 71,67 & 90,67 & 0,46 & 0,52 & 0,74 & $42,00 \mathrm{hi}$ & 1,97 \\
\hline $\mathrm{p} 0 \mathrm{k} 3$ & 31,33 & 73,00 & 91,00 & 0,47 & 0,53 & 0,74 & 53,33 ef & 2,49 \\
\hline $\mathrm{p} 1 \mathrm{k} 0$ & 29,56 & 70,00 & 90,33 & 0,46 & 0,51 & 0,73 & $46,00 \mathrm{~h}$ & 2,13 \\
\hline $\mathrm{p} 1 \mathrm{k} 1$ & 30,67 & 70,00 & 90,33 & 0,47 & 0,53 & 0,75 & $55,67 \mathrm{de}$ & 2,59 \\
\hline $\mathrm{p} 1 \mathrm{k} 2$ & 29,67 & 72,67 & 91,00 & 0,46 & 0,54 & 0,74 & 53,67 ef & 2,51 \\
\hline $\mathrm{p} 1 \mathrm{k} 3$ & 30,67 & 73,00 & 92,00 & 0,47 & 0,54 & 0,75 & $68,67 \mathrm{a}$ & 3,20 \\
\hline $\mathrm{p} 2 \mathrm{k} 0$ & 30,00 & 71,67 & 90,00 & 0,47 & 0,51 & 0,73 & $46,33 \mathrm{gh}$ & 2,01 \\
\hline $\mathrm{p} 2 \mathrm{k} 1$ & 31,33 & 70,67 & 90,33 & 0,47 & 0,53 & 0,73 & $59,67 \mathrm{~cd}$ & 2,65 \\
\hline $\mathrm{p} 2 \mathrm{k} 2$ & 31,00 & 74,00 & 91,00 & 0,47 & 0,54 & 0,74 & $63,00 \mathrm{bc}$ & 3,15 \\
\hline $\mathrm{p} 2 \mathrm{k} 3$ & 31,67 & 73,00 & 92,00 & 0,48 & 0,54 & 0,75 & $70,00 \mathrm{a}$ & 3,27 \\
\hline $\mathrm{p} 3 \mathrm{k} 0$ & 30,00 & 73,00 & 91,00 & 0,47 & 0,53 & 0,75 & $50,33 \mathrm{fg}$ & 2,35 \\
\hline $\mathrm{p} 3 \mathrm{k} 1$ & 31,33 & 72,67 & 91,67 & 0,47 & 0,54 & 0,75 & $67,67 \mathrm{a}$ & 3,15 \\
\hline $\mathrm{p} 3 \mathrm{k} 2$ & 31,00 & 73,67 & 92,33 & 0,49 & 0,54 & 0,75 & $66,33 \mathrm{ab}$ & 3,08 \\
\hline $\mathrm{p} 3 \mathrm{k} 3$ & 31,67 & 75,00 & 93,00 & 0,48 & 0,55 & 0,77 & $70,33 \mathrm{a}$ & 3,29 \\
\hline
\end{tabular}

Keterangan : angka rata-rata yang diikuti dengan huruf yang sama adalah berbeda tidak nyata menurut hasil uji lanjut dengan BNT taraf 5\%; tn = berpengaruh tidak nyata; * = berpengaruh nyata; $* *=$ berpengaruh sangat nyata; dan HST = hari setelah tanam, 


\subsection{Pembahasan}

Hasil sidik ragam menunjukkan bahwa perlakuan pupuk Procal berpengaruh nyata sampai berpengaruh sangat nyata terhadap tinggi tanaman pada umur 14 dan 40 hari setelah tanam serta pada saat panen., tetapi berpengaruh tidak nyata terhadap lingkar batang pada umur 40 hari setelah tanam. Hasil penelitian yang disajikan pada Tabel 1 (rekapitulasi) menunjukkan bahwa perlakuan berbagai dosis pupuk Procal (5 $\mathrm{g}_{\text {polibag }}{ }^{-1}, 10 \mathrm{~g}$ polibag $^{-1}$ dan $15 \mathrm{~g}$ polibag ${ }^{-1}$ ) menghasilkan pertumbuhan tanaman yang lebih tinggi dan lingkar batang tanaman tomat yang lebih besar dibandingkan dengan perlakuan tanpa pupuk Procal (p0). Makin tinggi dosis pupuk Procal yang diberikan diikuti dengan makin tinggi tanaman dan makin besar ukuran lingkar batang tanaman tomat yang dihasilkan. Hal ini disebabkan dengan pemberian pupuk Procal dapat memperbaiki $\mathrm{pH}$ tanah dan meningkatkan ketersediaan unsur hara yang dibutuhkan tanaman tomat. Pupuk Procal berperan meningkatkan $\mathrm{pH}$ tanah, meningkatkan kandungan klorofil yang diperlukan dalam proses fotosintesis dan mempercepat pertumbuhan tanaman (Mitratani, 2016). Selanjutnya pemupukan ditentukan oleh keadaan tanah seperti tanah-tanah pada lokasi studi menunjukkan reaksi tanah masam perlu dilakukan pemberian kapur (I Gede EB et al. 2017). Hasil Penelitian analisa tanah di Desa Giri Agung KTK kebanyakan rendah, adapun KTK yang rendah dapat ditingkatkan dengan penggunaan pupuk organik yang berguna untuk meningkatkan tanah menjadi gembur dan daya jerap tanah dan untuk meningkatkan kapasitas tukar kation sehingga dapat menampung apabila dilakukan penambahan unsur hara baik secara alami maupun dengan penambahan pupuk (Datu BP et al. 2013).
Hasil sidik ragam menunjukkan bahwa perlakuan pupuk Procal berpengaruh sangat nyata terhadap jumlah buah per tanaman dan berat buah per tanaman. Hasil penelitian disajikan pada Tabel 1 (rekapitulasi) menunjukkan bahwa perlakuan pemberian berbagai dosis pupuk Procal yaitu $5 \mathrm{~g}$ polibag $^{-1}$ (p1), $10 \mathrm{~g} \mathrm{polibag}^{-1}$ (p2) dan $15 \mathrm{~g}$ polibag ${ }^{1}$ (p3) menghasilkan jumlah buah per tanaman yang lebih banyak dan berat buah per tanaman yang lebih berat dibandingkan dengan perlakuan tanpa pupuk Procal (p0). Makin banyak buah tomat per tanaman) yang dihasilkan diikuti dengan meningkatnya berat buah per tanaman. Berat buah per tanaman paling tinggi dihasilkan pada perlakuan $15 \mathrm{~g}$ polibag $^{-1}$ (p3) yaitu $3,07 \mathrm{~kg}$ $\operatorname{tanaman}^{-1}$; disusul oleh perlakuan $10 \mathrm{~g}$ polibag $^{-1}$ (p2) yaitu 2,68 kg tanaman ${ }^{-1}$; perlakuan 5 g polibag $^{-1}(\mathrm{p} 1)$ yaitu $2,55 \mathrm{~kg}$ tanaman $^{-1}$ dan yang paling rendah dihasilkan pada perlakuan tanpa pupuk Procal (p0) yaitu 2,04 kg tanaman ${ }^{-1}$. Hal ini disebabkan pupuk Procal mengandung kapur aktif (Ca dan $\mathrm{Mg}$ ) dan dilengkapi dengan unsur hara makro dan unsur mikro, sehingga bila diberikan ke dalam tanah dapat meningkatkan $\mathrm{pH}$ tanah dan ketersediaan unsur hara bagi tanaman. Seperti dikemukakan oleh PT Pertani Persero (2016) bahwa pupuk Procal berperan bagi tanaman karena dapat meningkatkan $\mathrm{pH}$ tanah yang masam, meningkaktkan ketahanan tanaman dari hama dan penyakit, meningkatkan kandungan klorofil, dan mempercepat pertumbuhan tanaman.

Hasil sidik ragam menunjukkan bahwa perlakuan pupuk kandang kambing berpengaruh nyata sampai berpengaruh sangat nyata terhadap tinggi tanaman pada umur 40 hari setelah tanam dan pada saat panen, lingkar batang tanaman pada umur 14 hari setelah tanam dan pada saat panen, tetapi berpengaruh tidak nyata terhadap tinggi tanaman pada 
umur 14 hari setelah tanam dan lingkar batang pada umur 40 hari setelah tanam. Keadaan ini menunjukkan bahwa pemberian pupuk kandang kambing memberikan pengaruh yang berbeda-beda sesuai fase pertumbuhan tanaman. Seperti dijelaskan oleh Mulyani dan Sutejo (2003) bahwa kebutuhan tanaman akan bermacam-macam pupuk/unsur hara selama pertumbuhan dan perkembangannya adalah tidak sama, membutuhkan waktu/saat yang berbeda dan tidak sama banyaknya, sebab selama pertumbuhannya terdapat berbagai proses pertumbuhan yang intensitasnya berbedabeda.

Hasil penelitian yang disajikan pada Tabel 1 (rekapitulasi) menunjukkan bahwa perlakuan pemberian berbagai dosis pupuk kandang kambing (k1, k2, dan k3) menghasilkan tanaman tomat yang lebih tinggi dan lingkar batang yang lebih besar dibandingkan dengan perlakuan tanpa pemberian pupuk kandang kambing (k0). Keadaan ini disebabkan dengan pemberian pupuk kandang kambing dapat meningkatkan ketersediaan sejumlah unsur hara yang dibutuhkan tanaman tomat terutama unsur hara nitrogen $(\mathrm{N})$ yang sangat dibutuhkan untuk pertumbuhan vegetatif tanaman tomat. Seperti dikemukakan oleh Prihmantoro (2001) bahwa unsur hara $\mathrm{N}$ berperan untuk memacu pertumbuhan vegetatif tanaman.

Hasil sidik ragam menunjukkan bahwa perlakuan pupuk kandang kambing berpengaruh sangat nyata terhadap jumlah buah per tanaman dan berat buah per tanaman. Hasil penelitian disajikan pada Tabel 1 (rekapitulasi) menunjukkan bahwa perlakuan pemberian berbagai dosis pupuk kandang kambing yaitu $300 \mathrm{~g}$ polibag $^{-1}(\mathrm{k} 1) ; 600 \mathrm{~g}$ polibag $^{-1}(\mathrm{k} 2)$ dan $900 \mathrm{~g} \mathrm{polibag}^{-1}(\mathrm{k} 3)$ menghasilkan jumlah buah per tanaman yang lebih banyak dan berat buah per tanaman yang lebih berat dibandingkan dengan perlakuan tanpa pupuk kandang kambing (k0). Makin banyak buah tomat (jumlah buah per tanaman) yang dihasilkan diikuti dengan meningkatnya berat buah per tanaman. Berat buah per tanaman paling tinggi dihasilkan pada perlakuan $900 \mathrm{~g} \mathrm{polibag}^{-1}(\mathrm{k} 3)$ yaitu 2,97 $\mathrm{kg} \operatorname{tanaman}^{-1}$; disusul oleh perlakuan 600 $\mathrm{g} \mathrm{polibag}^{-1}(\mathrm{k} 2)$ yaitu $2,77 \mathrm{~kg}$ tanaman $^{-1}$; perlakuan $300 \mathrm{~g}$ polibag $^{-1}$ (k1) yaitu 2,61 $\mathrm{kg} \operatorname{tanaman}^{-1}$ dan yang paling rendah dihasilkan pada perlakuan tanpa pupuk kandang kambing (k0) yaitu $1,98 \mathrm{~kg}$ tanaman $^{-1}$. Hal ini disebabkan dengan pemberian pupuk kandang kambing dapat meningkatkan unsur hara makro dan unsur hara mikro yang dibutuhkan oleh tanaman, selain itu juga adanya perbaikan sifat fisik tanah dan sifat biologis tanah, sehingga tanaman dapat tumbuh dengan baik dan memberikan produksi buah yang tinggi. Sesuai dengan pendapat Lingga dan Marsono (2003) pemberian pupuk kandang selain memperbaiki kesuburan tanah, juga dapat memperbaiki sifat fisik dan biologis tanah. Dengan adanya perbaikan sifat-sifat tanah tersebut, maka tanaman dapat tumbuh dengan baik dan dapat menghasilkan produksi buah yang tinggi.

Hasil sidik ragam menunjukkan bahwa interaksi antara faktor pupuk Procal dan faktor pupk kandang kambing berpengaruh tidak nyata terhadap tinggi tanaman pada umur 14 dan 40 hari setelah tanam dan pada saat panen; lingkar batang tanaman pada umur 14 dan 40 hari setelah tanam dan pada saat panen; dan berat buah per tanaman; tetapi berpengaruh sangat nyata terhadap jumlah buah per tanaman. Keadaan tersebut menunjukkan bahwa antara faktor pupuk Procal dan faktor pupuk kandang kambing dapat saling bersamasama atau tidak secara bersama-sama (sendiri-sendiri) dalam mempengaruhi pertumbuhan dan hasil tanaman tomat. Seperti dijelaskan oleh Gomez dan 
Gomez (1995) bahwa dua faktor perlakuan dikatakan berinteraksi apabila pengaruh suatu faktor perlakuan berubah pada saat perubahan taraf faktor perlakuan lainnya. Selanjutnya dinyatakan oleh Steel dan Torrie (1991) bahwa bila pengaruh interaksi berbeda tidak nyata, maka disimpulkan bahwa diantara faktor-faktor perlakuan tersebut bertindak bebas satu terhadap lainnya. Kejadian ini disebabkan karena selama pertumbuhan dan perkembangan tanaman tomat terdapat fase-fase pertumbuhan yang berbeda-beda intensitasnya, sehingga kebutuhan unsur hara selama proses tersebut juga berbeda-beda atau tidak sama banyaknya.

Hasil penelitian yang disajikan pada Tabel 1 (rekapitulasi) menunjukkan bahwa pada setiap taraf perlakuan pupuk Procal yang dikombinasikan dengan berbagai dosis pupuk kandang kambing cenderung menghasilkan pertumbuhan tanaman yang lebih tinggi, lingkar batang tanaman yang lebih besar, jumlah buah per tanaman yang lebih banyak dan berat buah per tanaman yang lebih berat dibandingkan dengan tanpa pupuk kandang kambing. Demikian pula sebaliknya pada setiap taraf perlakuan pupuk kandang kambing yang dikombinasikan dengan berbagai dosis pupuk Procal cenderung menghasilkan pertumbuhan tanaman yang lebih tinggi, lingkar batang yang lebih besar, jumlah buah per tanaman yang lebih banyak dan berat buah per tanaman yang lebih berat dibandingkan dengan tanpa pupuk Procal. Keadaan ini disebabkan karena pemberian kedua pupuk tersebut dapat meningkatkan ketersediaan dan serapan unsur hara oleh tanaman tomat, sehingga tanaman dapat tumbuh baik dan memberikan hasil yang lebih baik. Seperti dikemukakan oleh Dwidjoseputro (1998) bahwa tanaman akan tumbuh subur apabila unsur hara yang dibutuhkannya tersedia dalam jumlah yang cukup. Setiap jenis pupuk kandang mempunyai cara aplikasi yang berbeda untuk berfungsi dengan baik terhadap tanaman tomat, pupuk kandang ayam lebih baik jika diaplikasikan menggunakan cara pop up dengan hasil mencapai 74,543 t/ha, pupuk kandang sapi lebih baik jika diaplikasikan menggunakan cara tebar dengan hasil mencapai 74,468 t/ha sedangkan pupuk kandang kambing lebih baik jika diaplikasikan menggunakan cara fertigasi dengan hasil mencapai 71,714 t/ha (Usfunan, 2016).

\section{KESIMPULAN}

Berdasarkan hasil penelitian dan pembahasan dapat diambil kesimpulan, yaitu sebagai berikut : Pemberian pupuk Procal berpengaruh nyata sampai berpengaruh sangat nyata terhadap tinggi tanaman pada umur 14 dan 40 hari setelah tanam dan pada saat panen, lingkar batang pada umur 14 hari setelah tanam dan pada saat panen, jumlah buah per tanaman, dan berat buah per tanaman. Berat buah paling tinggi dihasilkan pada perlakuan 15 g polibag $^{-1}$ (p3) yaitu 3,07 $\mathrm{kg}$ tanaman $^{-1}$, sedangkan yang paling rendah dihasilkan pada perlakuan tanpa pupuk Procal (p0) yaitu 2,04 kg tanaman 1 . Pemberian pupuk kandang kambing berpengaruh nyata sampai berpengaruh sangat nyata terhadap tinggi tanaman pada umur 40 hari setelah tanam dan pada saat panen, lingkar batang pada umur 14 hari setelah tanam dan pada saat panen, jumlah buah per tanaman, dan berat buah per tanaman. Berat buah paling tinggi dihasilkan pada perlakuan $900 \mathrm{~g} \mathrm{polibag}^{-1}$ (k3) yaitu $2,97 \mathrm{~kg}$ tanaman $^{-1}$, sedangkan yang paling rendah dihasilkan pada perlakuan tanpa pupuk kandang kambing (k0) yaitu $1,98 \mathrm{~kg}$ tanaman $^{-1}$. Hasil panen meningkat pada kombinasi pupuk kandang $5 \mathrm{t} \mathrm{ha}^{-1}$ dan pupuk hijau $5 \mathrm{t} \mathrm{ha}^{-1}$ sebesar $17,50 \mathrm{t} \mathrm{ha}^{-1}$ 
(meningkatkan $40 \%$ dibandingkan tanpa pupuk kandang dan pupuk hijau) serta kombinasi pupuk kandang $10 \mathrm{t} \mathrm{ha}^{-1}$ dan pupuk hijau $10 \mathrm{t} \mathrm{ha}^{-1}$ sebesar 19,06 $\mathrm{t} \mathrm{ha}^{-1}$ (meningkat 53\% dibandingkan tanpa pupuk kandang dan pupuk hijau). Hasil panen tomat sebesar 19,06 $\mathrm{t} \mathrm{ha}^{-1}$ tidak sebanding dengan hasil produksi umum petani sebesar 30-40 $\mathrm{t} \mathrm{ha}^{-1}$. Hal ini dikarenakan penelitian ini dilakukan secara organik, sedangkan yang dilakukan petani secara konvensional (Hasifah dkk., 20180

Interaksi antara pupuk Procal dan pupuk kandang kambing berpengaruh tidak nyata terhadap tinggi tanaman pada umur 14 dan 40 hari setelah tanam dan pada saat panen, lingkar batang pada umur 14 dan 40 hari setelah tanam dan pada saat panen, dan berat buah per tanaman, tetapi berpengaruh sangat nyata terhadap jumlah buah per tanaman.

\section{DAFTAR PUSTAKA}

Dwidjoseputro, D. (1998). Pengantar Fisiologi Tumbuhan. Jakarta: Gramedia.

Budiana, I. G. E., Jumani., Biantary, M.P. (2017). Evaluation of Soil Revegetation Success Rate Ex-Pit Coal Mine in Kitadin site Embalut Kutai in East Kalimantan. Agrifor, 16(2), 195208.

Gomez, K.A dan A.A Gomez. (1995). Prosedur Statistika untuk Penelitian Pertanian (Terjemahan Endang Syamsuddin dan J.S. Baharsjah). Jakarta: UI Press.

Hasifah, A. D., Sumarni, T., \& Sebayang, H. T. (2018). Pengaruh Pupuk Kandang Kambing Dan Pupuk Hijau (Crotalaria Juncea) Pada Pertumbuhan Dan Hasil Tanaman Tomat (Lycopersicon Esculentum
Mill). Jurnal Produksi Tanaman, 5(12).

Kartapradja dan Djuariah, (1992). Budidaya Tomat Mneggunakan Pupuk Kandang. Diakses 13 Maret 2015, dari http://fadhlandiraayandra.blogspot. com/ 2013/01/budidaya-tomatmenggunakan-pupukkandang.html.

Lingga, P dan Marsono. (2003). Petunjuk Penggunaan Pupuk. Jakarta: Penebar Swadaya.

Mitratani. (2016). Pembenah Tanah Majemuk Procal dari Mitratani Barokah sriwindarisejati. Diakses 2 Januari 2017, dari https://www.bukalapak.com/p/hobikoleksi/berkebun/pupuk-nutrisitanaman/asptve-jual-pembenahtanah-majemuk-procal.html.

Mul Mulyani, S dan A.G. Kartasapoetra. (2003). Pupuk dan Cara Pemupukan. Jakarta: Rineka Cipta.

Novizan, (2005). Budidaya Tomat Menggunakan Pupuk Kandang. Diakses 13 Maret 2015, dari http://fadhlandiraayandra.blogspot. com/2013/01/budidaya-tomatmenggunakan-pupukkandang.html.

Prihmantoro, H. (2001). Memupuk Tanaman Sayuran. Jakarta: Penebar Swadaya.

Pramana, D. B. (2013). Pertumbuhan Tanaman Gaharu (Aquilaria sp.) di Desa Giri Agung Kecamatan Sebulu Kabupaten Kutai Kartanegara Provinsi Kalimantan Timur. Agrifor, 11(2), 110-114.

PT Pertani Persero. (2016). Procal : Pembenah Tanah Majemuk. PT Pertani Persero, Jakarta. 
Steel, R.G.D dan J. H. Torrie. (1991). Prinsip dan Prosedur Statistika Suatu Pendekatan Biometrik. Jakarta: Gramedia Pustaka Utama.

Sutejo, (1987). Budidaya Tomat Menggunakan Pupuk Kandang. Diakses 13 Maret 2015, dari http://fadhlandiraayandra.blogspot. com/2013/01/budidaya-tomatmenggunakan-pupukkandang.html.
Usfunan, A. (2016). Pengaruh Jenis dan Cara Aplikasi Pupuk Kandang terhadap Pertumbuhan dan Hasil Tanaman Tomat (Lycopersicum esculentum Mill). Savana Cendana, 1(02), 68-73. 